\title{
Practical Recommendations for the Teachers on Optimization Process of the Students Majoring in Tourism
}

\author{
Tatyana Borisovna Lisitzina ${ }^{1}$, Natalya Iosifovna Kovaleva ${ }^{2}$, Albert Khanifovich Shaikhlislamov ${ }^{3}$, Venera \\ Nashatovna Minsabirova ${ }^{3}$, Almira Rubisovna Shaidullina ${ }^{3}$, Nailya Akhatovna Pavlova ${ }^{4} \&$ Yuliya Vladimirovna \\ Nevenchannaya $^{4}$ \\ ${ }^{1}$ Gzhel State Art and Industry Institute, Russia \\ ${ }^{2}$ The Moscow State Institute of Tourism Industry named after Y.A. Senkevich, Russia \\ ${ }^{3}$ Kazan Federal University, Russia \\ ${ }^{4}$ Naberezhnye Chelny Institute of Social-Pedagogical Technologies and Resources, Russia \\ Correspondence: Tatyana Borisovna Lisitzina, Ramensky region, Elektroizolyator, 67, 140155, Russia. E-mail: \\ tat2254@yandex.ru
}

Received: September 22, 2014 Accepted: November 5, $2014 \quad$ Online Published: December 2, 2014

doi:10.5539/ass.v11n1p154 URL: http://dx.doi.org/10.5539/ass.v11n1p154

\begin{abstract}
The problem under study is urgent as there is the lack of research by the Russian scientists concerning training and retraining of the teachers to implement professionally motivational training of the students majoring in "Tourism". This article presents guidelines for the teachers to optimize professionally motivational training of the students majoring in "Tourism", which are one of the most important conditions for the effective formation of the students' motivational sphere in continuous professional education. The article provisions are practically significant for the administration and teaching staff of the vocational education institutions in the course of organizing professionally motivational training of the students and also for the centers that provide training and professional retraining of the college and university teachers.
\end{abstract}

Keywords: methodological guidelines, teachers, professionally motivational training, students of the "Tourism" specialty

\section{Introduction}

Human activity has not always been conditioned objectively but also subjectively due to motivation, goal setting, willpower etc., so the effectiveness of the educational process depends largely on what kind of goals the students set, what needs and motivations have already been formed. Therefore, bringing up the students' aspiration for studying in the specialty "Tourism", the development of their positive attitudes to studying and work should be practiced in the work of every teacher and all the teaching staff as one of the important issues (Ilkevich, 2011; Lisitzina, 2007).

In common teaching practice the formation of person's motivational sphere still receives little attention, although the reason is burning. A certain part of students show a rather low level of interest to studying and profession, indifference to education, often negative attitude to knowledge. This happens because the teachers are not able to build up students' positive motives for learning and work (Ilkevich \& Ilkevich, 2013).

Considering the motivational sphere of the student we can state that according to the professionally-motivational training of the students majoring in "Tourism", in terms of the requirements for the teachers' efforts, they should be directed at: the concentration of the students' attention on the content of vocational training in the context of professional activity; the organization of professional activities, which actualize, develop and shape internal and external motivation; to activate such conditions for which the leading motives are awareness of the professional training as of public, social and personal value; the pursuit of high performance, requiring mobilization of physical, mental and moral qualities; creation of the situations, modeling, developing and molding general and professional motives in tourism, providing their connection and mutual transformation; at the development of the motivational sphere by formation general and professional skills, a high level of awareness; consolidation of the achieved level of professional motivation, the development of students' mental structures, maintaining commitment to professional self-development and self-education (Sergeev, 2008). 


\section{Literature Review}

The importance of professional motivation has always attracted the scientists, a variety of ways have been offered to solve it. The research made by E. P. Ilyin (2004), V. A. Popov, O. Y. Kondratyeva (1999), A. A. Rean (2008), A. A. Verbitsky, N. A. Bakshaeva (1998). However, updating the curriculum of professional education, development and implementation of new programs, textbooks and education facilities urgently require new ways of teaching and methods, new technologies capable to provide education performance and conditions for the development of students' professional motivation.

Solving these problems is inseparably connected with the training of the qualified teaching staff. Strategic directions of teacher training have been developed in the writings of S. I. Arhangelsky (1916), N. V. Kuzmina (2008) and others. Psychological and pedagogical rationale for future teachers training is discussed in the works of O. S.Gribenyuk, T. B. Gribenyuk (1998), V. V. Davydov (1986) and others. The questions relating to the teachers training to form students motivation have been considered in the studies by N. I. Meshkov, N. V. Haritonova (2010), D. Dubovitskaya (2003), A. G. Bugrimenko (2006). However, there are no studies of the training and professional development of the teaching staff to implement professionally motivational training of the students. In connection with the identified problem, the urgent issue of this article was to develop guidelines for the teachers aimed at effective implementation of professionally motivational training of the students majoring in "Tourism".

\section{Results and Discussions}

The authors have developed for the teachers the following methodological guidelines directed at effective professionally-motivational education of the students in the Tourism specialty.

1) in the course of professional activities it is necessary to constantly analyze the students' motivational sphere, to identify the level of the development of general and professional components of vocational education motivation. You should use the methods of studying motivational sphere: supervision over the students in the course of professional training and in free time, questionnaires, individual interviews, imitational pedagogical situations, etc. At all stages of professional training it is necessary to fix the parameters of the motivational sphere and professional skills, to find out what the motives, goals, emotions, types of attitudes towards vocational training the students of a particular study group demonstrate. On the basis of the received data, the analysis of the vocational training system and other factors, the conclusions about the possible reasons of the negative dynamics of the motivational sphere in professional activity and then the prospects for its correction are drawn;

2) the goals and objectives of vocational training should be designed taking into account the priority of its motivational component. One of the main purposes of any of the training sessions should be building the procedural side of the professional activity motivation, and this objective should be set in accordance with the detected level of professional motivation of the group students majority. The everyday procedural goals of creating motivational sphere are necessary to subject to the final three-pronged (national, social and personal) objective of the professionally motivational training (education) in college;

3) for the effective formation of motivation you need to know and take into account and actively develop the motivational possibilities of the components of the professional life system, to choose correct methods and means to promote general and professional motives, to analyze their compliance with the objectives of the professionally motivational education. In case of using special techniques of motivational sphere development, it is important to coordinate them with the possibilities of the curriculum and organizational forms of its implementation. The use of any tool and technique for building motivation must be timely, adequate and psychologically justified;

4) the selection and application of the methods of the motivational sphere development and formation should ensure mutual transformation of the general (educational) and professional motives. To achieve this, it is necessary to use the effect of all components of the vocational training system: content, methods, tools and organizational forms. It is necessary to create psycho-pedagogical conditions for the development of general and professional motives as the main courses in the motivational sphere of the student, interdependent development of which creates the dynamics of the vocational training sense. A permanent record of the interrelation betweem the general and professional motivation as a means of their formation is required. Junior courses education should provide for such effects on the students, such organization of their professional activity that would result in the awareness of importance and need for general culture for professional life. When conducting training sessions at the undergraduate courses the chosen methods and tools should provide awareness of the important 
role of culture in professional activity of the specialist in tourism, and reveal not only practical, professional, but also gnostic, ideological, social and educational importance of vocational training;

5) for the effective operation and development of the motivational sphere of the students the teacher has to interact with them at the level of "subject-subject" relationship, being aware that the student is a subject living in a constant and active interaction with the environment including the teacher. The instructor's role implies creating favorable conditions for cooperation and assistance to the student, who reveals his ability, develops and improves himself. Only such an approach complies with the humanistic paradigm of professional education, ensures the development of general and professional motives, their mutual transformation.

6 ) To form sustained cognitive interests in professionally motivational education of the students majoring in "Tourism" the teachers should follow the following forms, methods and tools: enthusiastic teaching; novelty of the educational material; historicism; connection with the fate of the people who has discovered them, showing practical application of the knowledge in connection with the life plans and orientations ; the use of new and innovative forms of teaching; alteration of forms and methods of teaching; problem-based teaching; heuristic teaching; computer support teaching; the use of multimedia systems; interactive computer-based means of teaching; collaborative learning (in pairs, small groups); testing knowledge and skills; showing the students' achievements; creating situations of success; competition (teammates, himself); creating a positive microclimate; confidence in the student; pedagogical tact and teacher's skills; teacher's attitude to his subject and the students; humanization of relations, etc.

7) it is necessary to constantly analyze the results of the students' motivational sphere formation, pay attention to the pedagogical conditions accompanying the changes, draw conclusions about the effectiveness of the methods and means of stimulation ; improve the teaching methods of motivation building. One must also consider the effect of the professional activity system components on the development of general and professional motives, seek for identification, maximum application and comprehensive development of the motivational component of the educational process elements. It is also reasonable to include the analysis and self-examination of the professionally motivational education headship and assess the extent of its impact on the quality of teaching, to inspire the development of positive motivation of all participants of the educational activity (Ilkevich \& Sukhodolova, 2011).

It should be noted that the foregoing recommendations are only a means to implement the principle of professionally motivational education, and the point is not in the study itself but in the study of the scientific foundations that they derive from (Vishtak, 2003). In the process of organizing students' professional activities it is unresonable to be blindly carried away by the prescribed rules and meticulously abide them, because it restrains teacher's creativity. But you can not just abandon any pedagogical recommendations.

To improve the quality of the professionally motivational education of the students majoring in Tourism and to study the present condition of the tourism development in the country and abroad we have developed a Program of retraining teachers for working with the students majoring in Tourism. The Program consists of an explanatory note, the thematic plan, the special course curriculum, test themes, model testing and the library resources.

The objectives of this program are to give the teachers an outline of working in the specialty "Tourism" about the tourism development strategy abroad and in Russia; about the geography of tourist travel; about sectoral structure of the service and tourism sectors; about the current state of the system of the specialist training for service sector; about the standard of professional tourist education; the qualitative characteristics of a modern model the specialist in "Tourism" in the region of the developed crafts and arts; about the curriculum of professionally motivational education of the students majoring in "Tourism"; the regional peculiarities of touristic Gzhel infrastructure. The objectives of the course have determined its structure, which includes 4 chapters. The classes are held in the form of round-table discussions, role-playing games, creative projects, etc. The college teachers who have passed this special course express unanimous opinion about the productivity of professionally motivational education. The developed program has been successfully applied for retraining teachers who had switched to work in the specialty "Tourism", for kindergarten teachers in Gzhel region, and school teachers in Gzhel region as kindergartens and schools are included into the system of continuous tourism education of Gzhel and also in the system of additional education for those wishing to take a course (the teachers of the optional education system).

The teachers of the Tourism department regularly attend seminars and conferences on the topic of the tourism development, visited tourism exhibitions. The teachers of the tourism department are working closely with the teachers of other universities, with employees of travel agencies, accommodation and catering enterprises, 
businesses and leisure activities enterprises, etc.. The themes of the future coursework and projects are developed together and intended for their practical application and implementation in life. For example there has been developed and approved such tourisic routes as « The Pearl of Gzhel - a health resort Konyashino -a hiking tour », " Gzhel-Shatura- the City of a hundred suns »- the bus tour with the elements of animation, " Porcelain Fairy Tale »- a walking tour, etc.

\section{Conclusions}

Therefore, we have developed the following recommendations for teachers to make effective professionally motivational training of the students majoring in "Tourism":

- it is necessary to constantly analyze the students' motivational sphere, to identify the level of development of general and professional components of motivation;

- the objectives and tasks of the education should be designed taking into account the priority of its motivational component;

- for the efficient formation of motivation the students need to know, take into account and choose the correct methods and means of stimulating general and professional motives of professional activity, to analyze their compliance level with the objectives of professionally motivational training;

- the selection and application of the methods of the students' motivational sphere development and formation should ensure mutual transformation of general and professional reasons;

- the teacher's role is creating enabling environment for cooperation and assistance to the student, who reveals his abilities, self-develops and improves;

- it is necessary to constantly analyze the results of the motivational sphere formation of the student, pay attention to the pedagogical conditions associated with these changes, to draw conclusions about the effectiveness of the methods and means, to promote its activity, improve teaching methods of motivation formation.

\section{References}

Arhangelsky, S. I. (1916). Historical views. Journal of the Ministry of National Education, 6, 113-126.

Bugrimenko, A. G. (2006). Internal and external training motivation of students of pedagogical high school. Psychological Science and Education, 4, 34-37.

Davydov, V. V. (1986). Problems of developmental education (p. 240). Moscow: Pedagogy.

Dubovitskaya, D. (2003). On the problem of diagnosis of learning motivation. Questions of Psychology, 3, 73-78.

Gribenyuk, O. S., \& Gribenyuk, T. B. (1998). Introduction to the work of the teacher-researcher (p. 57). Kaliningrad: 57.

Ilkevich, B. V. (2011). Problems and Prospects of Industrial Arts Education. Pedagogy, 6, 80-88.

Ilkevich, B. V., \& Ilkevich, K. B. (2013). Vocational and motivational art-industrial education. Gzhel: GGHPI Press.

Ilkevich, B. V., \& Sukhodolova, E. P. (2011). Industrial Art Education in Gzhel. Higher education today, 3, 58-61.

Ilyin, E. P. (2004). Motivation and motives. St. Petersburg.

Kuzmina, N. V. (2008). Psychology quality of specialist's professional activity (p. 76). St. Petersburg - Kolomna, Ryazan.

Lisitzina, T. B. (2007). Vocational and motivational training of students majoring in Tourism in the conditions of the region. Kazan: Thesis.

Meshkov, N. I., \& Haritonova, N. V. (2010). Pedagogy (p. 144). A short course of lectures: A tutorial. Saransk.

Popov, V. A., \& Kondratyeva. O. Y. (1999). Changing the motivational value orientations of students. Sociological Studies, 6, 34-37.

Rean, A. A. (2008). Adolescent psychology (p. 512). Moscow.

Sergeev, I. (2008). From policy management - to the contract. Higher Education in Russia, 4, 22-28.

Verbitsky, A. A., \& Bakshaeva. N. A. (1998). Development motivation in learning context. Herald high school, 
$1-2,47-50$.

Vishtak O. V. (2003). Motivational preferences of applicants and students. Sociological Studies, 2, 5-7.

\section{Copyrights}

Copyright for this article is retained by the author(s), with first publication rights granted to the journal.

This is an open-access article distributed under the terms and conditions of the Creative Commons Attribution license (http://creativecommons.org/licenses/by/3.0/). 